\title{
Fraxinus: A Plant with Versatile Pharmacological and Biological Activities
}

\author{
Iqra Sarfraz, ${ }^{1}$ Azhar Rasul, ${ }^{1}$ Farhat Jabeen, ${ }^{1}$ Tahira Younis, ${ }^{1}$ Muhammad Kashif Zahoor, \\ Muhammad Arshad, ${ }^{2}$ and Muhammad $\mathrm{Ali}^{1}$ \\ ${ }^{1}$ Department of Zoology, Faculty of Life Sciences, Government College University Faisalabad, Punjab 38000, Pakistan \\ ${ }^{2}$ Department of Zoology, Faculty of Life Sciences, University of Sargodha, Punjab 40100, Pakistan \\ Correspondence should be addressed to Azhar Rasul; drazharrasul@gmail.com
}

Received 31 August 2017; Revised 24 October 2017; Accepted 7 November 2017; Published 27 November 2017

Academic Editor: Rainer W. Bussmann

Copyright (C) 2017 Iqra Sarfraz et al. This is an open access article distributed under the Creative Commons Attribution License, which permits unrestricted use, distribution, and reproduction in any medium, provided the original work is properly cited.

\begin{abstract}
Fraxinus, a member of the Oleaceae family, commonly known as ash tree is found in northeast Asia, north America, east and western France, China, northern areas of Pakistan, India, and Afghanistan. Chemical constituents of Fraxinus plant include various secoiridoids, phenylethanoids, flavonoids, coumarins, and lignans; therefore, it is considered as a plant with versatile biological and pharmacological activities. Its tremendous range of pharmacotherapeutic properties has been well documented including anticancer, anti-inflammatory, antioxidant, antimicrobial, and neuroprotective. In addition, its bioactive phytochemicals and secondary metabolites can be effectively used in cosmetic industry and as a competent antiaging agent. Fraxinus presents pharmacological effectiveness by targeting the novel targets in several pathological conditions, which provide a spacious therapeutic time window. Our aim is to update the scientific research community with recent endeavors with specifically highlighting the mechanism of action in different diseases. This potentially efficacious pharmacological drug candidate should be used for new drug discovery in future. This review suggests that this plant has extremely important medicinal utilization but further supporting studies and scientific experimentations are mandatory to determine its specific intracellular targets and site of action to completely figure out its pharmacological applications.
\end{abstract}

\section{Introduction}

Plant derived natural products have been a continuous source of inspiration for human therapeutics despite enormous pharmaceutical industries relying on synthetic chemistry methods for drug discovery [1].

Over the centuries, natural products from plants have proven their worth as a primary source of novel chemical entities having therapeutic potential [2]. Natural products being enriched with variety of anticancer, antioxidant, and neuroprotective compounds have a great potential for drug discovery [3]. Currently, drug discovery from plants is a multidimensional research approach including botanical, phytochemical, molecular, and biological techniques providing important and new leads against pharmacological targets in various pathological conditions [4]. The first record of sophisticated medicinal system from natural products dates back to $2600 \mathrm{BC}$ in Mesopotamia, consisting of about 1000 medicines derived from botanical compounds and plant derivatives [5]. From 1981-2014, out of the 1562 drugs being approved, 1211 were small molecule approved drugs that are new chemical entities, which are nonsynthetic and obtained from natural products. Among them, 49\% of anticancer drugs belong to natural products $[6,7]$. In accordance with another record from 1981 to 2010, 1073 new drugs being approved, only $36 \%$ were synthetic entities and more than $50 \%$ were inspired or derived from nature [5]. About $80 \%$ of the population globally depends upon the botanical drugs mainly from medicinal plants [8].

Various studies conducted by researchers have reported that natural products have anticancer $[9,10]$, antibacterial [11], antifungal [12], antiviral [13], antioxidant [14, 15], anthelmintic [16], and anti-inflammatory [17, 18] activities. Particularly well-cited examples of natural products obtained from medicinal plants that have become prominent in modern pharmacotherapy as anticancer agents, include 


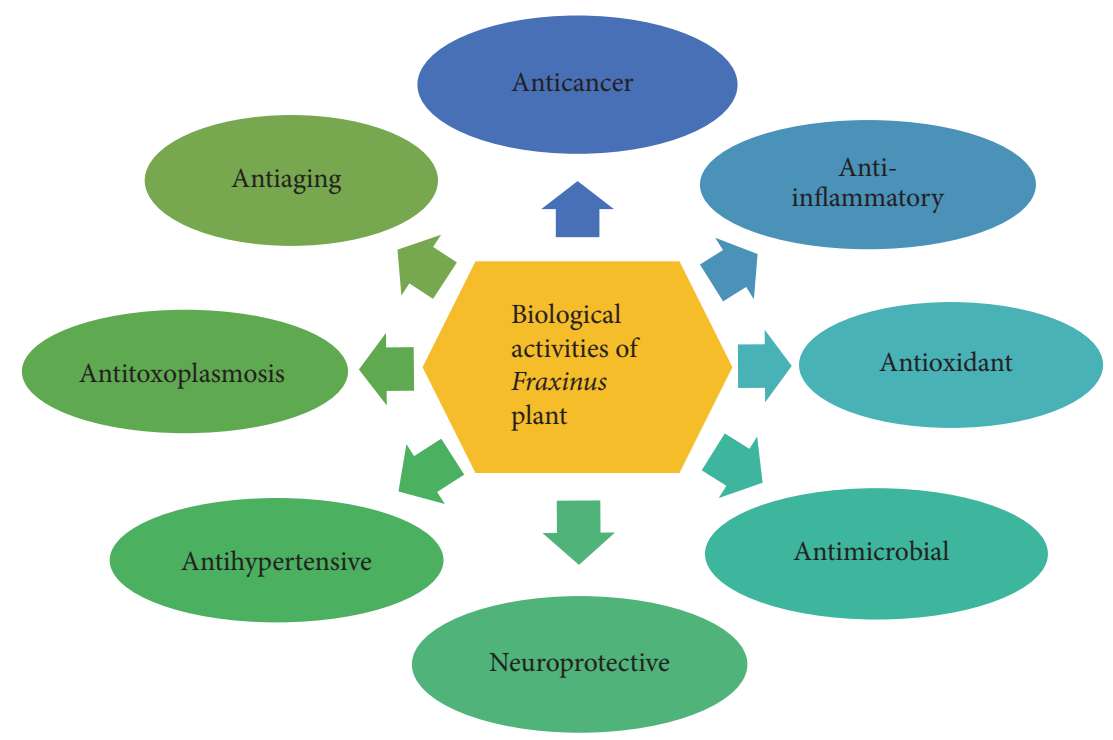

FIgURE 1: Biological activities of Fraxinus plant.

vinblastine and vincristine from Catharanthus roseus (Madagascar periwinkle), paclitaxel, and its derived compounds from Taxus species and camptothecin and its derivatives from Camptotheca acuminata Decne (Chinese tree) [5]. Cholinesterase inhibitor, galanthamine, as neuroprotective agent in Alzheimer's disease was firstly isolated from Galanthus nivalis L. [19]. Artemisinin, a potential antimalarial agent, was initially derived from Chinese medicinal herb Artemisia annua L. [20].

Traditionally, plant based drugs and medicinal plants have been employed for the treatment of humans and livestock in Pakistan and these medicinal plants play a valuable role in health care system in different areas of Pakistan [21].

Fraxinus, a member in the Oleaceae family, commonly known as ash tree [22] is found in various regions of world such as in western and eastern France [23], north American [24], north east Asia [25], China [26], north Pakistan, India, Afghanistan, Morocco, and Algeria. In northern areas of Pakistan, root bark and leaves of Fraxinus plant have been traditionally used for the cure of malaria and pneumonia [27]. A range of chemical constituents including secoiridoids, phenylethanoids, lignans, flavonoids, and coumarins has been isolated from Fraxinus plant. Metabolites and extracts from this plant have been found to possess variety of biological activities such as anticancer, anti-inflammatory, antioxidative, antimicrobial, hepatoprotective, antiallergic, skin regenerating, and diuretic $[28,29]$.

Esculetin, esculin, fraxin, and fraxetin are some of the pharmacologically active components isolated from different species of Fraxinus plant (Figure 2). Esculetin has been extensively used in Chinese herbal medicine due to its vast pharmacological activities such as antioxidant, anticancer, antibacterial, and anti-inflammatory [30].

This article is an effort to summarize the available information on pharmacological activities of different compounds isolated from traditional medicinal plant Fraxinus commonly known as ash tree. The searched literature highlights recent advances and scientific literature were checked through different sites, Elsevier ScienceDirect and PubMed, and relevant medical journals. The compiled data will hopefully update the scientific researchers with cotemporary endeavors in described field. We use "Fraxinus," "Fraxinus and biological activity," "medicinal plants," "anti-inflammatory," "anticancer," and "anti-oxidant" as key words for search.

\section{Biological Activities of Fraxinus Plant}

Fraxinus plant has been accounted for its wide spectrum of biological activities including anticancer, antiinflammatory, neuroprotective, antioxidant, anticytotoxic, antiaging, antimicrobial, and antihypertensive (Figure 1). Several in vivo and in vitro studies have been executed to describe its medicinal properties and to investigate the mechanism of action. Aggregated data have revealed a variety of bioactive medicinal components from different species of Fraxinus plant that exhibit various biological activities (Table 1).

2.1. Anticancer Activity. Phytochemicals obtained from medicinal plants, herbs, seeds, and fruits such as phenolic compounds (terpenoids, flavonoids, and carotenoids) have shown promising effects in suppressing proliferation and thus are anticarcinogenic [62]. Synthetic drugs have limited clinical utility as they are invariably associated with several toxic effects and drawbacks such as poor pharmacodynamic properties and nonselectivity [63]. Cell signaling pathways are the main pillars behind cell communication as they are essential for the regulation of cell proliferation and survival. Impairments in transduction pathways or cell signaling lead to various pathological conditions such as cancer [64]. Regulatory circuits and molecular machineries that govern cellular function and fate are mainly disrupted by oncogenic 


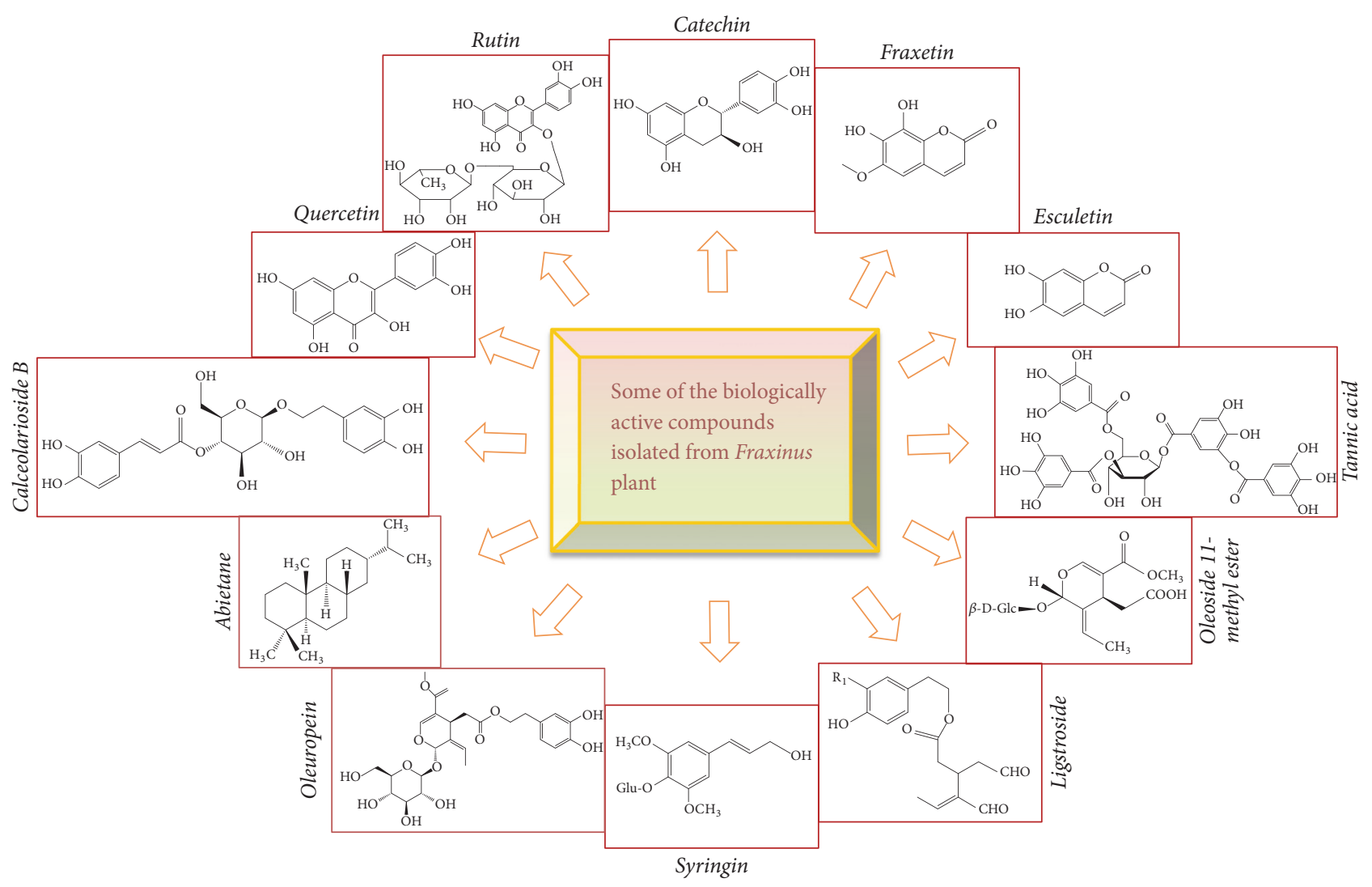

FIGURE 2: Some of the biologically active compounds isolated from Fraxinus plant.

mutations, conferring tumor cells towards various traits that assist their malignant behavior. Various hallmarks underlie the establishment of tumor cells: substantiating angiogenesis, tissue invasion, disruption of apoptosis, limitless duplication potential, being unresponsive to antigrowth signals, metabolic reprogramming, and genomic imbalance [65]. Natural products are valuable anticancer lead structures for cancer drug discovery. Accumulated data by researchers commend that apoptosis induction in cancerous cells can result from various biological chemopreventive and chemotherapeutic agents [66-71].

Various studies have revealed that Fraxinus plant is a notable biological drug candidate and has ability to inhibit carcinogenesis by targeting various signaling networks proteins associated with tumor cell multiplication (Figure 3). Here, we have reviewed anticancer activities of Fraxinus plant with an intent to provide a clear image to researchers about this medically important plant. Future efforts are required for the systematic identification of molecular targets for different compounds isolated from Fraxinus plant to enhance the possibilities of acquiring breakthrough vision in the field. Based upon previous researches, methanolic extract with bioactive components including polyphenols, flavonoids, and sterols from Fraxinus micrantha leads to induction of DNA fragmentation and production of NO thus conferring cells towards apoptosis in breast cancer cell line, MCF-7 [54]. Mistletoe extract obtained from host tree Fraxinus showed cytotoxicity against various cancerous cells including chronic myeloid leukemia K562 cells, human multiple myeloma RPMI-8226 cells, and murine leukemia L1210 cells via JNK$1 / 2$, caspase-9, and p38 MAPK activation, Mcl-1 downregulation, and inhibition of PKB and ERK-1/2 phosphorylation. Abnobaviscum F extract specifically targets Mcl-1 at mRNA stage thus contributing to the activation of intrinsic caspase pathway. JNK-1/2 mediated caspase activation induced the proteolysis of PKB and PARP, which leads to cell death [56]. Stimulation of intrinsic caspase pathway and downregulation of cellular GSH in K562 lead to induction of apoptosis [56]. Fraxinus excelsior, a novel herb, showed antiproliferative properties against numerous human cancerous cell lines: SKLC6 (lung carcinoma), AGS (Caucasian gastric adenocarcinoma), PLC/PRF/5 (liver hepatoma), SW742 (colorectal adenocarcinoma), A375 (melanoma cancer), and MCF-7 (breast ductal carcinoma) [55]. Glycosides isolated from the ethanolic extract of the bark of Fraxinus sieboldiana resulted in induction of apoptosis via activation of pro-caspase- 8 in colorectal cancer HCT-8 cells [46]. Abietane extracted from Fraxinus sieboldiana exhibits cytotoxic activities against human ovarian A2780 cells and A549 (lung carcinoma) [57]. Further research work is mandatory to fill the gaps by mainly focusing on the molecular targets of these plant extracts in extrinsic and intrinsic mitochondrial apoptosis pathways. Data concerning many perspectives of the genus Fraxinus such as mechanism of action, phytochemistry (detail of bioactive components), and clinical trials employing scientific technologies is still very restricted which demand 
TABLE 1: Compounds isolated from various species of Fraxinus plant and their biological activities.

\begin{tabular}{|c|c|c|c|c|}
\hline Plant species & Isolated compounds & Parts used & Biological activities & References \\
\hline Fraxinus angustifolia & $\begin{array}{l}\text { Tannic acid, catechin quercetin, } \\
\text { rutin }\end{array}$ & Bark, leaves & $\begin{array}{l}\text { Antioxidant, anti-inflammatory, } \\
\text { wound healing potential }\end{array}$ & {$[31]$} \\
\hline Fraxinus excelsior & $\begin{array}{l}\text { Nuzhenide, GI3, GI5, ligstroside, } \\
\text { oleoside 11-methyl ester, } \\
1^{\prime \prime \prime} \text {-O-beta-D-glucosylformoside, } \\
\text { excelsides A, excelsides B, } \\
\text { oleoside dimethyl ester, } \\
\text { coumarins }\end{array}$ & Seeds & $\begin{array}{l}\text { Antihypertensive, } \\
\text { antihypertriglyceridemia, } \\
\text { adipocyte differentiation } \\
\text { inhibitory activity, antidiabetic, } \\
\text { antihyperglycaemic, } \\
\text { anti-inflammatory, } \\
\text { antirheumatic }\end{array}$ & [32-35] \\
\hline Fraxinus rhynchophylla $\mathrm{C}$ & $\begin{array}{l}\text { Hydroxyframoside B } \\
2^{\prime \prime} \text {-hydroxyoleuropein, } \\
\text { oleuropein, ligstroside, syringin, } \\
\text { esculin, fraxetin, fraxetin-8-O- } \\
{\left[11^{\prime} \text {-methyl-oleosidyl- }\left(7^{\prime} \rightarrow\right.\right.} \\
\left.\left.6^{\prime \prime}\right)\right] \text {-beta-D-glucopyranoside, } \\
\text { esculetin }\end{array}$ & $\begin{array}{l}\text { Stem bark, dried stem } \\
\text { bark, root bark }\end{array}$ & $\begin{array}{l}\text { Pancreatic lipase inhibitory } \\
\text { activity, inhibitor of adipocyte } \\
\text { differentiation in 3T3-L1 cells, } \\
\text { neuroprotective (protection } \\
\text { against Abeta (25-35)-induced } \\
\text { neuronal toxicity), } \\
\text { antidyslipidemia, renoprotective, } \\
\text { metal and free radical induced } \\
\text { LDL oxidation inhibitor, } \\
\text { antiatherosclerosis, antioxidant, } \\
\text { PTP1B inhibitor, } \\
\text { antitoxoplasmosis, } \\
\text { glutamate-induced neuronal } \\
\text { HT-22 cell death inhibition, } \\
\text { hepatoprotective }\end{array}$ & {$[36-43]$} \\
\hline Fraxinus griffithii & $\begin{array}{l}\text { 7-epi-7-O-(E)-caffeoylloganic } \\
\text { acid, griffithosides C }\end{array}$ & Leaves & Antioxidative & {$[44]$} \\
\hline Fraxinus sieboldiana & $\begin{array}{l}\text { Abietane, C20-norabietane, } 6 \text {, } \\
\text { 7-di-O-beta-D- } \\
\text { glucopyranosylesculetin, } \\
\text { aromatic glycosides, } \\
\text { plantasioside, Calceolarioside B, } \\
\text { Esculetin }\end{array}$ & Stem bark & $\begin{array}{l}\text { Anticarcinogenic \{cytotoxic } \\
\text { activities against } \mathrm{A} 549 \text { and } \\
\left.\mathrm{A} 2780\left\{\mathrm{IC}_{50}=6.0 \mu \mathrm{M}, 1.7 \mu \mathrm{M}\right\}\right\}, \\
\text { protective against } \mathrm{H} 5 \mathrm{~N} 1 \text { avian } \\
\text { influenza virus, inhibition } \\
\text { against the discharge of } \\
\beta \text {-glucuronidase in } \\
\text { platelet-activating factor induced } \\
\text { polymorphonuclear rat } \\
\text { leukocytes, antioxidative, TNF- } \alpha \\
\text { secretion inhibitor (IC50 }= \\
1.6 \mu \mathrm{M}) \text {, inhibition against liver } \\
\text { microsomal lipid peroxidation } \\
\text { induced by Fe }(+2) \text {-cystine, } \\
\text { anticancer against human colon } \\
\text { cancer cell line }(\mathrm{HCT}-8) \text { with } \\
\mathrm{IC}_{50}=3.4 \mu \mathrm{M}, \mathrm{HIV} \text { inhibitor } \\
\left(\mathrm{IC}_{50}=0.1 \mathrm{mg} / \mathrm{ml} \text { and } 0.5 \mathrm{mg} / \mathrm{ml}\right)\end{array}$ & {$[45-47]$} \\
\hline Fraxinus chinensis & Esculin, esculetin, chinensisol & Twig skin, trunk bark & $\begin{array}{l}\text { Antioxidant against DPPH } \\
\text { radicals, antiphotoaging, } \\
\text { quinone reductase (QR) } \\
\text { inducing activity }\end{array}$ & {$[48,49]$} \\
\hline Fraxinus mandshurica & Calceolarioside A & Leaves & $\begin{array}{l}\text { Immunosuppressant (inhibition } \\
\text { of IL-2 and IgE production in } \\
\text { mouse spleen cells and U266 } \\
\text { cells) }\end{array}$ & {$[50]$} \\
\hline Fraxinus dimorpha & (E)-Nerolidol, eugenol & Leaves & $\begin{array}{l}\text { Antioxidant, antifungal }(\mathrm{MIC}= \\
1.8-3.8 \mathrm{mg} / \mathrm{mL})\end{array}$ & [51] \\
\hline Fraxinus ornus & Esculin & Stem bark & $\begin{array}{l}\text { Anti-inflammatory against } \\
\text { zymosan- and } \\
\text { carrageenan-induced paw } \\
\text { oedema }\end{array}$ & [52] \\
\hline
\end{tabular}


TABle 1: Continued.

\begin{tabular}{|c|c|c|c|c|}
\hline Plant species & Isolated compounds & Parts used & Biological activities & References \\
\hline Fraxinus bungeana & Esculetin, fraxetin & & $\begin{array}{l}\text { Analgesic, anti-inflammatory } \\
\text { (superoxide scavenging effects on } \\
\text { the xanthine-xanthine } \\
\text { oxidase-cytochrome c system) }\end{array}$ & {$[53]$} \\
\hline
\end{tabular}

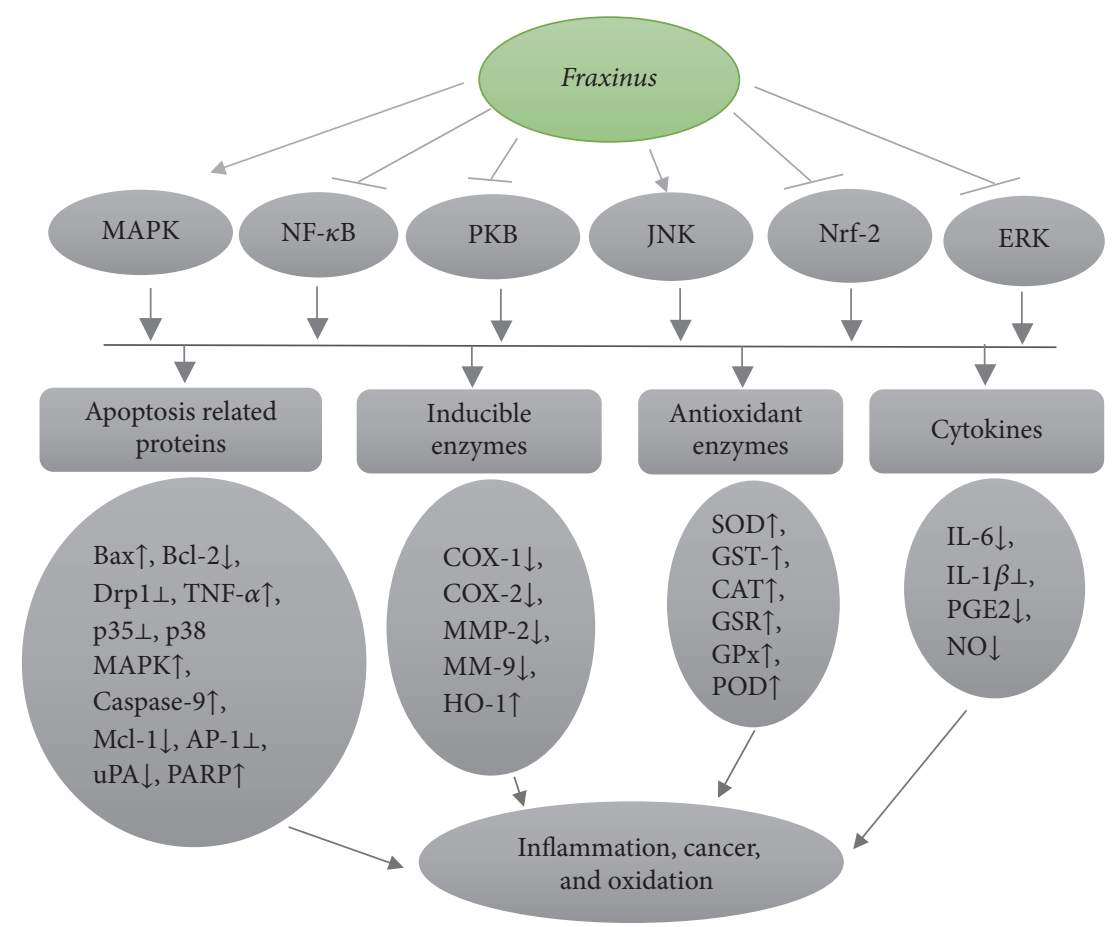

FIGURE 3: A diagram representing the molecular targets and mechanism of action for Fraxinus plant resulting in chemopreventive, antiinflammatory, and antioxidant activity. Fraxinus plant and its isolated compounds cause effective inhibition of protein kinase B, nuclear factor$\kappa \mathrm{B}$, regulator of antioxidant metabolizing enzymes (Nrf-2), extracellular signal transducers (ERK), and modulation of mitogen activated protein kinases (MAPK) and c-Jun N-terminal kinase (JNK) followed by activity modulation of various apoptosis related factors, inducible enzymes, antioxidant enzymes, and cytokines which are associated with proliferation, inflammation, and other pathological conditions.

for supplementary studies peculiarly in humans. The details of all the compiled information concerning the effective inhibitory concentrations and molecular targets of bioactive components isolated from Fraxinus species are recorded in Table 2.

2.2. Anti-Inflammatory Activity. Even though inflammatory response varies among different diseases, principally diseased condition is linked with the production of prostaglandins which are formed from arachidonate by the action of cyclooxygenase (COX) isoenzymes. Antiinflammatory drugs work by inhibition of enzymes COX1 and COX-2 thus downregulating the production of prostaglandins. Proposed adverse effects of nonsteroidal type anti-inflammatory drugs (NSAIDs) such as renal and gastric toxicity provoke the need of alternatives with cyclooxygenases specific inhibitors [72]. Herbal medicines such as STW 1 (Phytodolor) with an active component obtained from Fraxinus excelsior are an acceptable substitute to COX-2inhibitors such as rofecoxib and NSAIDs [73].
Fraxinus plant extract and its isolated compounds have a potential to modulate the activity of various key enzymes associated with inflammatory response (Figure 3). Oleuropein, phenolic compound isolated from the leaves of Fraxinus rhynchophylla, showed anti-inflammatory effects on BV-2 microglial cells via suppression of proinflammatory response by effective inhibition of Drpl-dependent mitochondrial fission [58]. Crude methanolic extract from the leaves of Fraxinus xanthoxyloides downregulated the production of inflammatory mediators and influx of leukocytes during in vitro and in vivo studies [27]. The 5-methoxyl aesculetin (MOA) from dried bark of Fraxinus rhynchophylla abrogates inflammatory response by its capability to block the activation of MAPK and activator protein-1 (AP-1) in RAW 264.7 cells. Much remains to be discovered about MOA as a propitious therapeutic agent for inflammatory diseases [59]. Screening of methanolic leave extracts from Fraxinus floribunda in rats suggests its significant pain relieving effects in inflammatory conditions [60]. Inhibition of myeloperoxidase (an enzyme released by triggered granulocytes and reported to produce 
TABLE 2: Molecular targets of Fraxinus plant in various cancer types.

\begin{tabular}{|c|c|c|c|c|}
\hline Type of cancer & Cell lines & EC50/conc. & Molecular targets & References \\
\hline Breast & MCF-7 & $18.95 \mu \mathrm{g} / \mathrm{ml}, 35.622 \mu \mathrm{g} / \mathrm{ml}$ & $\mathrm{NO} \uparrow$ & {$[54,55]$} \\
\hline Leukemia & K562, RPMI-8226, L1210 & $20 \mu \mathrm{g} / \mathrm{ml}$ & $\mathrm{PKB}$ phosphorylation $\perp$, Mcl-1 $\downarrow$, ERK- $1 / 2 \perp$ & {$[56]$} \\
\hline Gastric & AGS & $37.338 \mu \mathrm{g} / \mathrm{ml}$ & & [55] \\
\hline Colon & SW742, HCT-8 & $31.092 \mu \mathrm{g} / \mathrm{ml}, 3.4 \mu \mathrm{M}$ & & {$[46,55]$} \\
\hline Lung & SKLC6, A549 & $68.072 \mu \mathrm{g} / \mathrm{ml}, 6.0 \mu \mathrm{M}$ & & {$[55,57]$} \\
\hline Skin & A375 & $51.849 \mu \mathrm{g} / \mathrm{ml}$ & & {$[55]$} \\
\hline Ovary & A2780 & $1.7 \mu \mathrm{M}$ & & [57] \\
\hline Liver & $\mathrm{PLC} / \mathrm{PRF} / 5$ & $21.036 \mu \mathrm{g} / \mathrm{ml}$ & & {$[55]$} \\
\hline
\end{tabular}

TABLE 3: Anti-inflammatory properties of Fraxinus plant against various disease models and its molecular targets.

\begin{tabular}{|c|c|c|c|c|}
\hline Assay & Organism tested & Dose/conc. & Molecular targets & References \\
\hline $\begin{array}{l}\text { Anti-inflammatory effect of } \\
\text { oleuropein on LPS-induced } \\
\text { BV-2 microglial cells }\end{array}$ & $\begin{array}{l}\text { In vitro (BV-2 murine } \\
\text { microglial cells) }\end{array}$ & & $\begin{array}{c}\text { ERK } \perp, N F-\kappa B \perp, \text { LPS-induced } \\
\text { Drpl dephosphorylation } \perp, \\
\text { ROS } \perp\end{array}$ & {$[58]$} \\
\hline $\begin{array}{l}\text { Protective effects of } \\
\text { methanolic extract from } F \text {. } \\
\text { xanthoxyloides leaves on } \\
\text { inflammatory mediators }\end{array}$ & $\begin{array}{c}\text { In vitro (LPS-activated RAW } \\
264.7 \text { cells, TNF- } \alpha \text { activated } \\
\text { NF-kB in } 293 / \text { NF-kB-Luc } \\
\text { HEK cells), in vivo (rat) }\end{array}$ & $\begin{array}{c}5.98 \mu \mathrm{g} / \mathrm{ml} \text { (Luc HEK cells), } \\
6.59 \mu \mathrm{g} / \mathrm{ml} \text { (RAW } 264.7 \text { cells), } \\
200 \mathrm{mg} / \mathrm{kg} \text { (in vivo) }\end{array}$ & $\begin{array}{l}\text { TNF- } \alpha \text { induced production of } \\
\text { NF- } \kappa \mathrm{B} \perp, \mathrm{NO} \downarrow \text { (in vitro), } \\
\text { IL- } 6 \downarrow, \mathrm{PGE} 2 \downarrow \text {, TNF- } \alpha \downarrow \text {, } \\
\text { LPS-instigated NO } \perp \text { (in vivo) }\end{array}$ & {$[27]$} \\
\hline $\begin{array}{l}\text { Modulation of cytokine } \\
\text { expression by 5-methoxyl } \\
\text { aesculetin (MOA) in } \\
\text { LPS-stimulated RAW264.7 } \\
\text { macrophages }\end{array}$ & In vitro (RAW 264.7 cells) & $25.32 \mu \mathrm{g} / \mathrm{mL}$ & $\begin{array}{c}\text { TNF- } \alpha \perp \text {, interleukin- } 6 \perp \text {, } \\
\text { interleukin- } 1 \beta \perp, \mathrm{ERK} 1 / 2 \perp \text {, } \\
\text { p38 MAPK } \perp, \mathrm{AP}-1 \perp, \mathrm{PGE}_{2} \perp \text {, } \\
\text { cyclooxygenase- } 2 \downarrow, \mathrm{TNF}-\alpha \\
\text { mRNA } \downarrow \text {, nitric oxide }(\mathrm{NO}) \\
\text { synthase } \downarrow\end{array}$ & {$[59]$} \\
\hline $\begin{array}{l}\text { Protective activities of } \\
\text { methanolic extract of Fraxinus } \\
\text { floribunda Wallich against } \\
\text { inflammation }\end{array}$ & $\begin{array}{l}\text { Wistar Albino rats, Swiss } \\
\text { Albino mice }\end{array}$ & 400 mg/kg/p.o. & & {$[60]$} \\
\hline $\begin{array}{l}\text { Anti-inflammatory effects of } \\
\text { Fraxinus excelsior during in } \\
\text { vivo and in vitro studies }\end{array}$ & In vitro, in vivo & & $\begin{array}{c}\text { T-cell activation } \perp \text {, } \\
\text { arachidonic acid cascade } \perp\end{array}$ & {$[61]$} \\
\hline
\end{tabular}

harmful agent hypochlorous acid) by extracts from Fraxinus excelsior along with Populus tremula recommends its usage as anti-inflammatory drug [61]. Lipopolysaccharide (LPS) and interferon-gamma induced murine macrophagelike RAW 264.7 cells treatment by Fraxinus rhynchophylla extract showed an inhibition trend towards the amount of iNOS protein in dose-dependent manner suggesting its possible application as anti-inflammatory agent in autoimmune and chronic inflammatory diseases [74]. Inhibition of dihydrofolate reductase by aqueous ethanolic extract of Fraxinus excelsior is one of the possible mechanisms behind its anti-inflammatory activity [75]. Most of the available scientific literature has limited information about treatment duration, relevant doses, storage conditions, and controls for the assessment of bioefficacy of active components in plant extract arousing the need for further investigations. The detail of all the compiled knowledge about molecular targets of Fraxinus plant extracts is listed in Table 3.

2.3. Antioxidant Activity. In living systems free radicals as singlet oxygen $\left({ }^{1} \mathrm{O}_{2}\right)$, superoxide anion $\left(\mathrm{O}_{2}{ }^{--}\right)$, hydroxyl radicals $\left(\mathrm{OH}^{*}\right)$, and other reactive oxygen species such as peroxynitrate, hydrogen peroxide $\left(\mathrm{H}_{2} \mathrm{O}_{2}\right), \mathrm{OH}$, and hypochlorous acid are known to have damaging role and deleterious effects on cellular functions and paly outstanding role in several diseases [76]. Free radicals have capability to interact with cellular components and thus causing DNA damage, lipid peroxidation, and protein injuries [77]. Researchers have described a wide variety of plant extracts that have hepatoprotective activities usually associated with antioxidant activity as excessive production of free radicals overpowers the natural protective system causing hepatic damage [78-80].

Antioxidants are substances that have ability to reduce the harmful effects of these free radicals. Exogenous antioxidants primarily include natural as well as synthetic compounds having radical scavenging abilities. Hepatoprotective activities by Fraxinus xanthoxyloides leave extract against carbon tetrachloride $\left(\mathrm{CCl}_{4}\right)$ induced oxidative stress in hepatic tissues in rats (Rattus novergicus) reduce the level of $\mathrm{H}_{2} \mathrm{O}_{2}$ and significantly increase the regenerative capacity of liver antioxidant enzymes (CAT, POD, SOD, GST, and GSR) $\left(\mathrm{EC}_{50}=400 \mathrm{mg} / \mathrm{kg}\right)$ [76]. Oral administration of ethanolic extract from Fraxinus rhynchophylla [FR (EtOH)] against 
$\mathrm{CCl}_{4}$ induced hepatic fibrosis resulted in protective effects by its free radical scavenging ability against hepatocellular fibrosis in rats. FR (EtOH) has much action accordingly to dose: so $0.1,0.5 \mathrm{~g}$, and $1.0 \mathrm{~g} / \mathrm{kg}$ body weight significantly upregulated the action of liver antioxidant enzymes (such as CAT, SOD, and GPx) and decreased the high activities of sGOT and sGPT. Furthermore, FR (EtOH) could cause inhibition of protein expression of UPA, TIMP-1, MMP-2, and MMP-9 in rats [81]. A novel compound fraxetin isolated from Fraxinus rhynchophylla showed dual antioxidative functions against metal and free radicals induced low density lipoprotein (LDL) oxidation. At low concentration $(1-5 \mu \mathrm{M})$ it has direct protective effects and at higher concentration fraxetin activated the nuclear factor Nrf-2/ARE, which were linked with the increased activity of glutathione S-transferase-alpha and $\mathrm{HO}-1$. Fraxetin mediated induction of $\mathrm{HO}-1$ has potential to enhance the detoxification of free radicals. [39]. Fraxetin showed protective activities against liver microsomal lipid peroxidation induced by $\mathrm{Fe}(+2)$ in rats with inhibitory rate of $60 \%$ at a concentration of $10(-6) \mathrm{mol} \times \mathrm{L}(-1)$ [45]. Esculetin, a major component from Fraxinus chinensis extract (FCE), represented the strongest antioxidant activity against DPPH radicals associated with superoxide anions in xanthine oxidase system and esculetin also effectively inhibited the oxidation of $7^{\prime}$ dichlorodihydrofluorescein diacetate (CMH2DCFDA) and 5-(6-)dichloromethyl-2' [48]. Esculetin (coumarin) isolated from Fraxinus rhynchophylla notably meliorated $\mathrm{CCl}_{4}$ induced hepatic toxicity by downregulating the aspartate aminotransferase and serum alanine aminotransferase and via upregulation of GSH-Px, SOD, and CAT and thus prevented the pathological condition associated with tissue injury [43]. Rutin isolated from Fraxinus angustifolia have notable radical scavenging activity via inhibition of ethane release from Fenton-type oxidants induced 1keto-4-methylthiobutyrate (KMB) and inhibition of nitrogen monoxide (NO) release from hydroxylamine [82]. Mechanism of action of Fraxinus plant is mainly associated with the upregulation of various antioxidant enzymes (Figure 3).

2.4. Antimicrobial Activity. Scientists have demonstrated a variety of chemical compounds from plants, notably the secondary phytochemicals known to exhibit antimicrobial activity and which are effective against multidrug resistance microorganisms. The concern of resistance provoked the need of effective and eco-friendly alternatives [83]. Treatment of bacterial cultures (Staphylococcus aureus, Pseudomonas aeruginosa, Streptococcus lactis, Escherichia coli, and Mycobacterium phlei) with plant extracts using microplate resazurin assay for screening showed that Fraxinus pennsylvanicca exhibits notable antibacterial activities with MICs ranging from 62.5 to $1000 \mu \mathrm{g} / \mathrm{ml}$ [84].

Fraxetin (one of the main constituents of Fraxinus rhynchophylla) inhibitory effects against Staphylococcus aureus proliferation were investigated by treatment of bacterial cultures with fraxetin at a concentration of $0.05 \mathrm{mg} / \mathrm{ml}$. The mechanisms associated with antimicrobial action of fraxetin indicated the highest inhibition of topoisomerase-1 and topoisomerase 2 and remarkable increase in membrane permeability. Additionally, macromolecules such as DNA, RNA, and proteins are decreased to $33.86,48.96$, and $55.74 \%$ [85]. Further studies are required with more microbial species to assemble data related to Fraxinus plant that can act as potential antimicrobial agent.

2.5. Neuroprotective Activity. Neuroprotective mechanism for natural compounds depends upon their free radical scavenging ability generated by neurotoxin and oxidative induced processes in nerve cells [86]. Glutamate as the abundant mammalian neurotransmitter and excessive extracellular level of glutamate cause the activation of glucose receptors and overloading of neuronal calcium $\left(\mathrm{Ca}^{+2}\right)$ level that leads to glutamate induced neuronal injury [87, 88]. Oleuropein isolated from Fraxinus rhynchophylla can be used as neuroprotective agents against colchicine induced neurodegenerative diseases as it significantly recovered memory and learning retention [89]. An attempt to elucidate the mechanism of action of Fraxinus plant extract is that it increases the Bcl-2 expression, inhibits the translocation of mitochondrial apoptosis-inducing factor (AIF) to the cytoplasm, and decreases the Bax expression. Furthermore, it causes the regulation of phosphorylation of Drp1 at serine 637 and reduction in the number of cells with fragmented mitochondria [42].

F. rhynchophylla have remarkable inhibitory activity against neuronal cell damage induced by Abeta (25-35) by downregulating the activity and expression of caspase-3, reducing the cleaved PARP and DNA fragmentation with an effective concentration of $20 \mu \mathrm{M}$ [90]. Moreover esculin isolated from Fraxinus sieboldiana blume has neuroprotective properties on cytotoxicity stimulated by dopamine in human neuroblastoma SH-SY5Y cell line via downregulating the GSH levels, upregulating the SOD activity, inhibiting the apoptosis-inducing factor (AIF), the discharge of cytochrome $\mathrm{c}$ and the expression of activated caspase 3 , and regulating the Bax, Bcl-2, and p53 proteins [91]. Most of the studies focus on few chemical constituents and data about the pharmacokinetics of the whole plant extract is limited.

2.6. Antifungal Activity. Protective products originated from natural substances mainly from plants as alternative to synthetic fungicides is the spotlight issue nowadays [92]. Natural antimicrobial products are inexpensive and they have a potential for implementation in fungal pathogenic systems [93]. The antifungal activity against Schizosaccharomyces octosporus and Candida albicans cultures with inhibitory concentration value ranging from 62.5 to $1000 \mu \mathrm{g} / \mathrm{mL}$ shows that Fraxinus pennsylvanicca plant extract exhibits notable antifungal activity [84].

2.7. Antihypertensive. Researchers have described a variety of bioactive compounds found in natural substances that play vital roles in prevention and treatment of cardiovascular diseases caused due to vasodilation and hypertension [94]. Administration of Fraxinus excelsior L. seed extract (FESE) orally at a daily dose of $20 \mathrm{mg} / \mathrm{kg}$ or $40 \mathrm{mg} / \mathrm{kg}$ body weight of animal in spontaneously hypertensive rats 
improved acetylcholine relaxation in aorta, decreased plasma and liver malondialdehyde levels, and increased plasma antioxidant capacity [95]. Protective hypotensive effects of Fraxinus excelsior extract were evaluated in spontaneously hypertensive and normotensive rats and oral administration of $20 \mathrm{mg} / \mathrm{kg} /$ day for about 3 weeks resulted in significant decrease in systolic blood pressure (SBP) [96]. Nuzhenide and GI3, the novel compounds from Fraxinus excelsior L. seed extract (FXE), decrease the systolic blood pressure significantly in spontaneously hypertensive rats (SHR) and obese Zucker rats at a dose concentration of $200 \mathrm{mg} / \mathrm{kg}$ [32].

2.8. Antimalarial. An alarming situation of resistance against antimalarial drugs leads to the requirement of affordable treatment from medicinal plants [97]. Scientists have described antiplasmodium potential from variety of plant extracts [98]. In vitro studies to check the effects of lipo and hydrophilic extract from the bark of Fraxinus excelsior on the growth of asexual stages of Plasmodium falciparum suggest that it has significant inhibitory effects on the development of asexual stages of Plasmodium falciparum [99].

2.9. Antitoxoplasmosis. Toxoplasmosis, an intracellular parasitic protozoan infection caused by Toxoplasma gondii, is usually asymptomatic but has serious clinical manifestations in immunocompromised individuals [100]. Herbal extracts that have important role in the regulation of immunity can serve as effective and secure medicine against toxoplasmosis [101]. Serious toxic effects associated with the application of antitoxoplasmosis drugs like sulfadiazine and pyrimethamine arouse the urgent need of safe and effective alternatives. In vitro evaluations of antitoxoplasma activity of oleuropein and its metabolites isolated from Fraxinus rhynchophylla showed a good efficacy and higher selectivity as an anti-T. gondii compound. $\left(\mathrm{EC}_{50}=139 \mathrm{mg} / \mathrm{ml}\right)$ [41]. However, the results are not sufficient and should be approved by related tests along with clinical trials. The culpable compound should be subjected to isolation from extract and purified for further inquiry.

2.10. Antiaging. Most of the plants that have high percentage of polyphenolic compounds have been widely used in cosmetics for their antiaging properties [102]. Esculetin from Fraxinus chinensis extract resulted in protective effects against photoaging via downregulating the MMP-1 mRNA in a dosedependent fashion due to its free radical scavenging nature [48].

\section{Other Biological Activities}

Some other biological activities of medically significant compounds isolated from Fraxinus species are as follows: diterpenes analogs from Fraxinus sieboldiana resulted in a prohibitory activity opposite to $\mathrm{H} 5 \mathrm{~N} 1$ avian influenza virus. Inhibitory concentration $\left(\mathrm{IC}_{50}\right)$ reported to be $4.8 \mu \mathrm{M}$ [57]. Evaluation of methanolic extracts from Fraxinus floribunda in rats at a dose concentration of $400 \mathrm{mg} / \mathrm{kg} / \mathrm{oral}$ reveals its significant antinociceptive properties and its potential for relieving pain in pathological conditions such as inflammation [60]. Polyphenolic compounds as catechin, rutin, quercetin, and tannic acid from Fraxinus angustifolia bark and leaf extracts incorporated with different nanovesicles to increase the skin bioavailability found to be effective for their wound healing potential which is associated with their antioxidant and anti-inflammatory activity [31]. Fraxinus excelsior bark extract for its free radical scavenging activities and for tyrosinase elastase and collagenase prohibitory activities suggest its use in dermocosmetic industry [103]. Glucevia, an effective Fraxinus excelsior herbal extract that competently balances fructosamine and blood glucose concentrations, significantly augmented adiponectin-leptin ratio in obese and overweight older rats via oral administration of Glucevia immediately after sugar rich meals [104, 105]. In vitro assessment of hydroxyframoside $\mathrm{B}$ isolated from ethanolic extract of stem bark of Fraxinus rhynchophylla provided an approach to decrease obesity via downregulating the pancreatic lipase activity thus restricting the absorption of lipid by pancreas [36]. Treatment of streptozotocin- (STZ) induced diabetic rats by Fraxinus angustifolia leaf extract (25 and $50 \mathrm{mg} / \mathrm{kg}$ ) resulting in considerable hypoglycemic effects with significant reduction in malondialdehyde levels in short interval of time providing a way for the treatment of diabetes [106]. Oral administration of hydroethanolic extracts from Fraxinus ornus at dose concentrations of 10 or $50 \mathrm{mg} / \mathrm{kg}$ body weight in nicotinamide-streptozotocininduced diabetic mice showed potent antihyperglycemic activity. Identification and isolation of lead structures from hydroethanolic extract for novel antidiabetic drug development are commended [107]. Fraxini cortex, a traditional Chinese medicinal plant, possesses significant antidiarrheal properties having a notable effect on $\mathrm{Cl}(-)$ transport as simply the diarrhea is altered movement of $\mathrm{Na}^{+}$and $\mathrm{Cl}^{-}$ ions [108]. Drugs that work to decrease the elevated blood pressure in body by increasing the amount of urine and urinary sodium excretion are known as diuretics. A study on herbal medicines has revealed that Fraxinus excelsior extract promotes diuresis and thus potentially can be used as hypotensive agent [109].

\section{Conclusions and Future Perspectives}

This review reveals that Fraxinus plant is a valuable drug candidate with its potential anticarcinogenic, anti-inflammatory, antioxidative, and neuroprotective properties. Various in vitro and in vivo studies results have demonstrated its several applications in biological systems. Stem bark, root bark, and leave extract of this plant have wide applications in traditional folk medicines since ancient times. Fraxinus plant derivative analogs along with pharmacodynamics and pharmacokinetics may also strengthen future advances. Fraxinus plant extracts can serve as template for new drug design and synthesis of new compounds for various human diseases treatments. To date, most of the researchers do not figure out the chemical ingredients of the plant extracts. Then, various pharmacological perspectives of Fraxinus plant such as proper dosage and clinical effectiveness are yet to be 
elucidated. There is a need to identify the toxicological limits for certain organs like liver and kidney. The molecular mechanism and exact protein targets of potent bioactive molecules from Fraxinus plant also deserve to be further investigated. With regard to ongoing investigations on Fraxinus plant's biological applications further scientific experimentations and safety profiling are required to make understandings more clear and obvious in the treatment and prevention of various diseases.

\section{Conflicts of Interest}

The authors declare that there are no conflicts of interest.

\section{Acknowledgments}

This study was supported by research grant from The Nagai Foundation Tokyo, Japan. The authors would also like to acknowledge Higher Education Commission (HEC), Pakistan, for providing access to related papers from various journals.

\section{References}

[1] Y. Luo, R. E. Cobb, and H. Zhao, "Recent advances in natural product discovery," Current Opinion in Biotechnology, vol. 30, pp. 230-237, 2014.

[2] A. Rasul, F. M. Millimouno, W. Ali Eltayb, M. Ali, J. Li, and $\mathrm{X}$. Li, "Pinocembrin: a novel natural compound with versatile pharmacological and biological activities," BioMed Research International, vol. 2013, Article ID 379850, 9 pages, 2013.

[3] A. L. Harvey, R. Edrada-Ebel, and R. J. Quinn, "The reemergence of natural products for drug discovery in the genomics era," Nature Reviews Drug Discovery, vol. 14, no. 2, pp. 111-129, 2015.

[4] M. J. Balunas and A. D. Kinghorn, "Drug discovery from medicinal plants," Life Sciences, vol. 78, no. 5, pp. 431-441, 2005.

[5] A. G. Atanasov, B. Waltenberger, and E. M. Pferschy-Wenzig, "Discovery and resupply of pharmacologically active plantderived natural products: a review," Biotechnology Advances, vol. 33, no. 8, pp. 1582-1614, 2015.

[6] D. J. Newman and G. M. Cragg, "Natural products as sources of new drugs from 1981 to 2014," Journal of Natural Products, vol. 79, no. 3, pp. 629-661, 2016.

[7] D. J. Newman, G. M. Cragg, and K. M. Snader, "Natural products as sources of new drugs over the period 1981-2002," Journal of Natural Products, vol. 66, no. 7, pp. 1022-1037, 2003.

[8] T. Sen and S. K. Samanta, "Medicinal plants, human health and biodiversity: a broad review," Advances in Biochemical Engineering/Biotechnology, vol. 147, pp. 59-110, 2015.

[9] N. Engel, A. Falodun, J. Kühn, U. Kragl, P. Langer, and B. Nebe, "Pro-apoptotic and anti-adhesive effects of four African plant extracts on the breast cancer cell line MCF-7," BMC Complementary and Alternative Medicine, vol. 14, no. 1, article 334, 2014.

[10] J. Paul, R. Gnanam, R. M. Jayadeepa, and L. Arul, "Anti cancer activity on graviola, an exciting medicinal plant extract vs various cancer cell lines and a detailed computational study on its potent anti-cancerous leads," Current Topics in Medicinal Chemistry, vol. 13, no. 14, pp. 1666-1673, 2013.
[11] V. Kuete, S. Alibert-Franco, K. O. Eyong et al., "Antibacterial activity of some natural products against bacteria expressing a multidrug-resistant phenotype," International Journal of Antimicrobial Agents, vol. 37, no. 2, pp. 156-161, 2011.

[12] A. Mollataghi, E. Coudiere, A. H. A. Hadi et al., "Antiacetylcholinesterase, anti- $\alpha$-glucosidase, anti-leishmanial and anti-fungal activities of chemical constituents of Beilschmiedia species," Fitoterapia, vol. 83, no. 2, pp. 298-302, 2012.

[13] M. Son, M. Lee, G.-H. Sung et al., "Bioactive activities of natural products against herpesvirus infection," Journal of Microbiology, vol. 51, no. 5, pp. 545-551, 2013.

[14] M. Alaniia, K. Shalashvili, T. Sagareishvili, N. Kavtaradze, and M. Sutiashvili, "Study of antioxidant activity of phenolic compounds from some species of Georgian flora," Georgian Medical News, vol. 222, no. 9, pp. 69-72, 2013.

[15] U. R. Chatterjee, S. S. Bandyopadhyay, D. Ghosh, P. K. Ghosal, and B. Ray, "In vitro anti-oxidant activity, fluorescence quenching study and structural features of carbohydrate polymers from Phyllanthus emblica," International Journal of Biological Macromolecules, vol. 49, no. 4, pp. 637-642, 2011.

[16] P. M. Guarrera, "Traditional antihelmintic, antiparasitic and repellent uses of plants in Central Italy," Journal of Ethnopharmacology, vol. 68, no. 1-3, pp. 183-192, 1999.

[17] A. Azab, A. Nassar, and A. N. Azab, "Anti-inflammatory activity of natural products," Molecules, vol. 21, no. 10, article A119, 2016.

[18] E. Fasano, S. Serini, N. Mondella et al., "Antioxidant and anti-inflammatory effects of selected natural compounds contained in a dietary supplement on two human immortalized keratinocyte lines," BioMed Research International, vol. 2014, Article ID 327452, 11 pages, 2014.

[19] M.-J. R. Howes, N. S. L. Perry, and P. J. Houghton, "Plants with traditional uses and activities, relevant to the management of Alzheimer's disease and other cognitive disorders," Phytotherapy Research, vol. 17, no. 1, pp. 1-18, 2003.

[20] S.-P. He, G.-Y. Tan, G. Li et al., "Development of a sensitive monoclonalantibody-based enzyme-linked immunosorbent assay for the antimalaria active ingredient artemisinin in the Chinese herb Artemisia annua L.," Analytical and Bioanalytical Chemistry, vol. 393, no. 4, pp. 1297-1303, 2009.

[21] H. Sher, R. W. Bussmann, R. Hart, and H. J. De Boer, "Traditional use of medicinal plants among Kalasha, Ismaeli and Sunni groups in Chitral District, Khyber Pakhtunkhwa province, Pakistan," Journal of Ethnopharmacology, vol. 188, pp. 57-69, 2016.

[22] M. Torres, O. Palomares, J. Quiralte, G. Pauli, R. Rodríguez, and M. Villalba, "An enzymatically active $\beta$-1,3-glucanase from ash pollen with allergenic properties: A particular member in the oleaceae family," PLoS ONE, vol. 10, no. 7, Article ID e0133066, 2015.

[23] J. F. Fernandez-Manjarres, P. R. Gerard, J. Dufour, C. Raquin, and N. Frascaria-Lacoste, "Differential patterns of morphological and molecular hybridization between Fraxinus excelsior L. and Fraxinus angustifolia Vahl (Oleaceae) in eastern and western France," Molecular Ecology, vol. 15, no. 11, pp. 3245-3257, 2006.

[24] S. R. Tanis and D. G. McCullough, "Host resistance of five fraxinus species to Agrilus planipennis (Coleoptera: Buprestidae) and effects of paclobutrazol and fertilization," Environmental Entomology, vol. 44, no. 2, pp. 287-299, 2015.

[25] D. D. Hinsinger, M. Gaudeul, A. Couloux, J. Bousquet, and N. Frascaria-Lacoste, "The phylogeography of Eurasian Fraxinus 
species reveals ancient transcontinental reticulation," Molecular Phylogenetics and Evolution, vol. 77, no. 1, pp. 223-237, 2014.

[26] P.-Q. Zhang, Y.-J. Liu, X. Chen, Z. Yang, M.-H. Zhu, and Y.-P. Li, "Pollution resistance assessment of existing landscape plants on Beijing streets based on air pollution tolerance index method," Ecotoxicology and Environmental Safety, vol. 132, pp. 212-223, 2016.

[27] T. Younis, M. R. Khan, M. Sajid, M. Majid, Z. Zahra, and N. A. Shah, "Fraxinus xanthoxyloides leaves reduced the level of inflammatory mediators during in vitro and in vivo studies," BMC Complementary and Alternative Medicine, vol. 16, no. 1, article 230, 2016.

[28] I. Kostova and T. Iossifova, "Chemical components of Fraxinus species," Fitoterapia, vol. 78, no. 2, pp. 85-106, 2007.

[29] I. Kostova, "Fraxinus ornus L," Fitoterapia, vol. 72, no. 5, pp. 471480, 2001.

[30] C. Liang, W. Ju, S. Pei, Y. Tang, and Y. Xiao, "Pharmacological activities and synthesis of esculetin and its derivatives: a minireview," Molecules, vol. 22, no. 3, article 387, 2017.

[31] K. Moulaoui, C. Caddeo, M. L. Manca et al., "Identification and nanoentrapment of polyphenolic phytocomplex from Fraxinus angustifolia: In vitro and in vivo wound healing potential," European Journal of Medicinal Chemistry, vol. 89, pp. 179-188, 2015.

[32] F. Montó, C. Arce, M. A. Noguera et al., "Action of an extract from the seeds of Fraxinus excelsior L. on metabolic disorders in hypertensive and obese animal models," Food \& Function, vol. 5, no. 4, pp. 786-796, 2014.

[33] N. Bai, K. He, A. Ibarra et al., "Iridoids from Fraxinus excelsior with adipocyte differentiation-inhibitory and PPAR $\alpha$ activation activity," Journal of Natural Products, vol. 73, no. 1, pp. 2-6, 2010.

[34] M. Maghrani, N.-A. Zeggwagh, A. Lemhadri, M. El Amraoui, J.-B. Michel, and M. Eddouks, "Study of the hypoglycaemic activity of Fraxinus excelsior and Silybum marianum in an animal model of type 1 diabetes mellitus," Journal of Ethnopharmacology, vol. 91, no. 2-3, pp. 309-316, 2004.

[35] S. Von Kruedener, W. Schneider, and E. F. Elstner, "A combination of Populus tremula, Solidgo virgaurea and Fraxinus excelsior as an anti-inflammatory and antirheumatic drug. A short review," Arzneimittel-Forschung, vol. 45, no. 2, pp. 169-171, 1995.

[36] J. H. Ahn, E. Shin, Q. Liu et al., "Secoiridoids from the stem barks of Fraxinus rhynchophylla with pancreatic lipase inhibitory activity," Natural Product Research, vol. 27, no. 12, pp. 1132-1135, 2013.

[37] K.-M. Choi, E. Shin, Q. Liu et al., "Hydroxyframoside B, a secoiridoid of fraxinus rhynchophylla, inhibits adipocyte differentiation in 3T3-L1 cells," Planta Medica, vol. 77, no. 10, pp. 1020-1023, 2011.

[38] Y.-H. Wang, Y.-H. Liu, G.-R. He, Y. Lv, and G.-H. Du, "Esculin improves dyslipidemia, inflammation and renal damage in streptozotocin-induced diabetic rats," BMC Complementary and Alternative Medicine, vol. 15, no. 1, article 402, 2015.

[39] P. T. Thuong, Y. R. Pokharel, M. Y. Lee et al., "Dual anti-oxidative effects of fraxetin isolated from Fraxinus rhinchophylla," Biological \& Pharmaceutical Bulletin, vol. 32, no. 9, pp. 1527-1532, 2009.

[40] K. Xiao, Q.-H. Song, S.-W. Zhang, and L.-J. Xuan, "Watersoluble constituents of the root barks of Fraxinus rhynchophylla (Chinese drug Qinpi)," Journal of Asian Natural Products Research, vol. 10, no. 2, pp. 205-210, 2008.
[41] J.-H. Jiang, C.-M. Jin, Y.-C. Kim, H.-S. Kim, W.-C. Park, and H. Park, "Anti-toxoplasmosis effects of oleuropein isolated from Fraxinus rhychophylla," Biological \& Pharmaceutical Bulletin, vol. 31, no. 12, pp. 2273-2276, 2008.

[42] M. H. Kim, J. Min, J. Y. Lee et al., "Oleuropein isolated from Fraxinus rhynchophylla inhibits glutamate-induced neuronal cell death by attenuating mitochondrial dysfunction," Nutritional Neuroscience, 2017.

[43] Y.-C. Tien, J.-C. Liao, C.-S. Chiu et al., "Esculetin ameliorates carbon tetrachloride-mediated hepatic apoptosis in rats," International Journal of Molecular Sciences, vol. 12, no. 6, pp. 40534067, 2011 .

[44] R. A. Macahig, L. Harinantenaina, K. Matsunami, H. Otsuka, Y. Takeda, and T. Shinzato, "Secoiridoid and iridoid glucosides from the leaves of Fraxinus griffithii," Journal of Natural Medicines, vol. 64, no. 1, pp. 1-8, 2010.

[45] S. Lin, M. T. Liu, S. J. Wang et al., "Coumarins from branch of Fraxinus sieboldiana and their antioxidative activity," China Journal of Chinese Materia Medica, vol. 33, no. 14, pp. 1708-1710, 2008.

[46] S. Lin, S. Wang, M. Liu et al., "Glycosides from the stem bark of Fraxinus sieboldiana," Journal of Natural Products, vol. 70, no. 5, pp. 817-823, 2007.

[47] H. J. Kim, Y. G. Yu, H. Park, and Y. S. Lee, "HIV gp41 binding phenolic components from Fraxinus sieboldiana var. angustata," Planta Medica, vol. 68, no. 11, pp. 1034-1036, 2002.

[48] B.-C. Lee, S. Y. Lee, H. J. Lee et al., "Anti-oxidative and photo-protective effects of coumarins isolated from Fraxinus chinensis," Archives of Pharmacal Research, vol. 30, no. 10, pp. 1293-1301, 2007.

[49] L. Wang, F. Sun, X. Zhang, Z. Ma, and L. Cheng, "A secoiridoid with quinone reductase inducing activity from Cortex fraxini," Fitoterapia, vol. 81, no. 7, pp. 834-837, 2010.

[50] Y. Chen, G. Xue, F. Liu, and X. Gong, "Immunosuppressive effect of extracts from leaves of Fraxinus Mandshurica Rupr," Bioengineered, vol. 8, no. 3, pp. 212-216, 2017.

[51] S. M'sou, M. Alifriqui, and A. Romane, "Phytochemical study and biological effects of the essential oil of Fraxinus dimorpha Coss \& Durieu," Natural Product Research, vol. 31, no. 23, pp. 2797-2800, 2017.

[52] Z. Stefanova, H. Neychev, N. Ivanovska, and I. Kostova, "Effect of a total extract from Fraxinus ornus stem bark and esculin on zymosan- and carrageenan-induced paw oedema in mice," Journal of Ethnopharmacology, vol. 46, no. 2, pp. 101-106, 1995.

[53] W. S. Chang, C. C. Lin, S. C. Chuang, and H. C. Chiang, "Superoxide anion scavenging effect of coumarins," American Journal of Chinese Medicine, vol. 24, no. 1, pp. 11-17, 1996.

[54] S. Kumar and P. Kashyap, "Antiproliferative activity and nitric oxide production of a methanolic extract of Fraxinus micrantha on Michigan Cancer Foundation-7 mammalian breast carcinoma cell line," Journal of Intercultural Ethnopharmacology, vol. 4, no. 2, pp. 109-113, 2015.

[55] S. Sardari, M. A. Shokrgozar, and G. Ghavami, "Cheminformatics based selection and cytotoxic effects of herbal extracts," Toxicology in Vitro, vol. 23, no. 7, pp. 1412-1421, 2009.

[56] Y.-K. Park, Y. R. Do, and B.-C. Jang, "Apoptosis of K562 leukemia cells by Abnobaviscum $\mathrm{F}^{\circledR}$, a European mistletoe extract," Oncology Reports, vol. 28, no. 6, pp. 2227-2232, 2012.

[57] S. Lin, Y. Zhang, M. Liu et al., "Abietane and C20-norabietane diterpenes from the stem bark of Fraxinus sieboldiana and their biological activities," Journal of Natural Products, vol. 73, no. 11, pp. 1914-1921, 2010. 
[58] J. Park, J.-S. Min, U. Chae et al., "Anti-inflammatory effect of oleuropein on microglia through regulation of Drpl-dependent mitochondrial fission," Journal of Neuroimmunology, vol. 306, pp. 46-52, 2017.

[59] L. Wu, X. Li, H. Wu et al., "5-Methoxyl aesculetin abrogates lipopolysaccharide-induced inflammation by suppressing MAPK and AP-1 pathways in RAW 264.7 cells," International Journal of Molecular Sciences, vol. 17, no. 3, article 315, 2016.

[60] S. Lingadurai, L. K. Nath, P. K. Kar, S. E. Besra, and R. V. Joseph, "Anti-inflammatory and anti-nociceptive activities of methanolic extract of the leaves of Fraxinus floribunda wallich," African Journal of Traditional, Complementary and Alternative Medicines, vol. 4, no. 4, pp. 411-416, 2007.

[61] S. Von Kruedener, W. Schneider, and E. F. Elstner, "Effects of extracts from Populus tremula L., Solidago virgaurea L. and Fraxinus excelsior L. on various myeloperoxidase systems," Arzneimittel-Forschung, vol. 46, no. 8, pp. 809-814, 1996.

[62] T. Rabi and A. Bishayee, "Terpenoids and breast cancer chemoprevention," Breast Cancer Research and Treatment, vol. 115, no. 2, pp. 223-239, 2009.

[63] P. Singh, N. Ngcoya, and V. Kumar, "A review of the recent developments in synthetic anti-breast cancer agents," AntiCancer Agents in Medicinal Chemistry, vol. 16, no. 6, pp. 668685, 2016.

[64] A. R. Ferreira, J. Felgueiras, and M. Fardilha, "Signaling pathways in anchoring junctions of epithelial cells: Cell-to-cell and cell-to-extracellular matrix interactions," Journal of Receptors and Signal Transduction, vol. 35, no. 1, pp. 67-75, 2015.

[65] F. G. Giancotti, "Deregulation of cell signaling in cancer," FEBS Letters, vol. 588, no. 16, pp. 2558-2570, 2014.

[66] A. Rasul, R. Bao, M. Malhi et al., "Induction of apoptosis by costunolide in bladder cancer cells is mediated through ROS generation and mitochondrial dysfunction," Molecules, vol. 18, no. 2, pp. 1418-1433, 2013.

[67] A. Rasul, B.-J. Zhao, J. Liu et al., "Molecular mechanisms of casticin action: An update on its antitumor functions," Asian Pacific Journal of Cancer Prevention, vol. 15, no. 21, pp. 90499058, 2014.

[68] A. Rasul, B. Yu, L. Zhong, M. Khan, H. Yang, and T. Ma, "Cytotoxic effect of evodiamine in SGC-7901 human gastric adenocarcinoma cells via simultaneous induction of apoptosis and autophagy," Oncology Reports, vol. 27, no. 5, pp. 1481-1487, 2012.

[69] A. Rasul, M. Khan, B. Yu, T. Ma, and H. Yang, "Xanthoxyletin, a coumarin induces $S$ phase arrest and apoptosis in human gastric adenocarcinoma SGC-7901 cells," Asian Pacific Journal of Cancer Prevention, vol. 12, no. 5, pp. 1219-1223, 2011.

[70] A. Rasul, C. Ding, X. Li et al., "Dracorhodin perchlorate inhibits PI3K/Akt and NF- $\kappa$ B activation, up-regulates the expression of p53, and enhances apoptosis," Apoptosis, vol. 17, no. 10, pp. 11041119, 2012.

[71] A. Rasul, B. Yu, M. Khan et al., "Magnolol, a natural compound, induces apoptosis of SGC-7901 human gastric adenocarcinoma cells via the mitochondrial and PI3K/Akt signaling pathways," International Journal of Oncology, vol. 40, no. 4, pp. 1153-1161, 2012.

[72] M. K. Urban, "COX-2 specific inhibitors offer improved advantages over traditional NSAIDs," Orthopedics, vol. 23, no. 7, pp. s761-s764, 2000.

[73] K.-J. Gundermann and J. Müller, "Phytodolor ${ }^{\circledR}$-effects and efficacy of a herbal medicine," Wiener Medizinische Wochenschrift, vol. 157, no. 13-14, pp. 343-347, 2007.
[74] N.-Y. Kim, H.-O. Pae, Y.-S. Ko et al., "In vitro inducible nitric oxide synthesis inhibitory active constituents from Fraxinus rhynchophylla," Planta Medica, vol. 65, no. 7, pp. 656-658, 1999.

[75] E. Strehl, W. Schneider, and E. F. Elstner, "Inhibition of dihydrofolate reductase activity by alcoholic extracts from Fraxinus excelsior, Populus tremula and Solidago virgaurea," Arzneimittel-Forschung, vol. 45, no. 2, pp. 172-173, 1995.

[76] T. Younis, M. R. Khan, and M. Sajid, "Protective effects of Fraxinus xanthoxyloides (Wall.) leaves against CCl4 induced hepatic toxicity in rat," BMC Complementary and Alternative Medicine, vol. 16, no. 1, article 407, 2016.

[77] E. M. Ede, "Cellular oxidative stress and antioxidant enzymes," Microreviews in Cell and Molecular Biology, vol. 1, no. 1, pp. 1-3, 2012.

[78] S. Chen, M. Ju, Y. Luo et al., "Hepatoprotective and antioxidant activities of the aqueous: extract from the rhizome of phragmites Australis," Zeitschrift fur Naturforschung C, Journal of Biosciences, vol. 68, no. 11-12, pp. 439-444, 2013.

[79] S. A. Ganie, T. A. Dar, B. Zargar et al., "Antioxidant and hepatoprotective effects of crataegus songarica methanol extract," Journal of Environmental Pathology, Toxicology and Oncology, vol. 33, no. 2, pp. 131-143, 2014.

[80] A. B. Saba, O. M. Onakoya, and A. A. Oyagbemi, "Hepatoprotective and in vivo antioxidant activities of ethanolic extract of whole fruit of Lagenaria breviflora," Journal of Basic and Clinical Physiology and Pharmacology, vol. 23, no. 1, pp. 27-32, 2012.

[81] W.-H. Peng, Y.-C. Tien, C.-Y. Huang et al., "Fraxinus rhynchophylla ethanol extract attenuates carbon tetrachlorideinduced liver fibrosis in rats via down-regulating the expressions of UPA, MMP-2, MMP-9 and TIMP-1," Journal of Ethnopharmacology, vol. 127, no. 3, pp. 606-613, 2010.

[82] U. Rohnert, W. Schneider, and E. F. Elstner, "Superoxidedependent and -independent nitrite formation from hydroxylamine: inhibition by plant extracts," Zeitschrift fur Naturforschung C, Journal of Biosciences, vol. 53, no. 3-4, pp. 241-249, 1998.

[83] Y.-S. Lee, S.-H. Han, S.-H. Lee et al., "Synergistic effect of tetrandrine and ethidium bromide against methicillin-resistant Staphylococcus aureus (MRSA)," Journal of Toxicological Sciences, vol. 36, no. 5, pp. 645-651, 2011.

[84] J. Vandal, M. M. Abou-Zaid, G. Ferroni, and L. G. Leduc, "Antimicrobial activity of natural products from the flora of Northern Ontario, Canada," Pharmaceutical Biology, vol. 53, no. 6, pp. 800-806, 2015.

[85] H. Wang, D. Zou, K. Xie, and M. Xie, "Antibacterial mechanism of fraxetin against Staphylococcus aureus," Molecular Medicine Reports, vol. 10, no. 5, pp. 2341-2345, 2014.

[86] A. Wąsik and L. Antkiewicz-Michaluk, "The mechanism of neuroprotective action of natural compounds," Pharmacological Reports, vol. 69, no. 5, pp. 851-860, 2017.

[87] L. Zhang, L. Hao, H. Wang et al., "Neuroprotective effect of resveratrol against glutamate-induced excitotoxicity," Advances in Clinical and Experimental Medicine, vol. 24, no. 1, pp. 161-165, 2015.

[88] Y.-L. Lan, J. Zhao, and S. Li, "Estrogen receptors' neuroprotective effect against glutamate-induced neurotoxicity," Neurological Sciences, vol. 35, no. 11, pp. 1657-1662, 2014.

[89] S. Pourkhodadad, M. Alirezaei, M. Moghaddasi et al., "Neuroprotective effects of oleuropein against cognitive dysfunction induced by colchicine in hippocampal CA1 area in rats," The Journal of Physiological Sciences, vol. 66, no. 5, pp. 397-405, 2016. 
[90] E.-J. Yang, S.-I. Kim, H.-Y. Ku et al., "Syringin from stem bark of fraxinus rhynchophylla protects a $\beta(25-35)$-induced toxicity in neuronal cells," Archives of Pharmacal Research, vol. 33, no. 4, pp. 531-538, 2010.

[91] D.-L. Zhao, L.-B. Zou, S. Lin, J.-G. Shi, and H.-B. Zhu, "Antiapoptotic effect of esculin on dopamine-induced cytotoxicity in the human neuroblastoma SH-SY5Y cell line," Neuropharmacology, vol. 53, no. 6, pp. 724-732, 2007.

[92] I. Lahmar, H. Belghith, F. Ben Abdallah, and K. Belghith, "Nutritional composition and phytochemical, antioxidative, and antifungal activities of Pergularia tomentosa L," BioMed Research International, vol. 2017, Article ID 6903817, 9 pages, 2017.

[93] A. Mohammadi, H. Nazari, S. Imani, and H. Amrollahi, "Antifungal activities and chemical composition of some medicinal plants," Journal de Mycologie Médicale, vol. 24, no. 2, pp. e1-e8, 2014.

[94] C. Y. Kwan, "Vascular effects of selected antihypertensive drugs derived from traditional medicinal herbs," Clinical and Experimental Pharmacology \& Physiology. Supplement, vol. 22, no. 1, pp. S297-S299, 1995.

[95] N. López-Carreras, S. Fernández-Vallinas, M. Miguel, and A. Aleixandre, "Long-term effect of an aqueous Fraxinus excelsior L. seed extract in spontaneously hypertensive rats," International Journal of Hypertension, vol. 2014, Article ID 565212, 8 pages, 2014.

[96] M. Eddouks, M. Maghrani, N.-A. Zeggwagh, M. Haloui, and J.B. Michel, "Fraxinus excelsior L. evokes a hypotensive action in normal and spontaneously hypertensive rats," Journal of Ethnopharmacology, vol. 99, no. 1, pp. 49-54, 2005.

[97] N. K. Kaushik, A. Bagavan, A. A. Rahuman et al., "Evaluation of antiplasmodial activity of medicinal plants from North Indian Buchpora and South Indian Eastern Ghats," Malaria Journal, vol. 14, no. 1, article 564, 2015.

[98] K. C. Chinsembu, "Plants as antimalarial agents in Sub-Saharan Africa," Acta Tropica, vol. 152, pp. 32-48, 2015.

[99] B. Aydin-Schmidt, W. Thorsell, and M. Wahlgren, "Carolus linnaeus, the ash, worm-wood and other anti-malarial plants," Scandinavian Journal of Infectious Diseases, vol. 42, no. 11-12, pp. 941-942, 2010.

[100] J. C. Sepulveda-Arias, L. A. Veloza, and L. E. Mantilla-Muriel, "Anti-Toxoplasma activity of natural products: a review," Recent Patents on Anti-Infective Drug Discovery, vol. 9, no. 3, pp. 186194, 2014.

[101] Z. Y. Yu, B. D. Zhang, J. Y. Ning et al., "Advances in researches on mechanism of anti-Toxoplasma Chinese herbal medicine," Chinese Journal of Schistosomiasis Control, vol. 27, no. 5, pp. 555557, 559, 2015.

[102] T. Mizutani and H. Masaki, "Anti-photoaging capability of antioxidant extract from Camellia japonica leaf," Experimental Dermatology, vol. 23, supplement 1, pp. 23-26, 2014.

[103] J. Hubert, A. Angelis, N. Aligiannis et al., "In vitro dermocosmetic evaluation of bark extracts from common temperate trees," Planta Medica, vol. 82, no. 15, pp. 1351-1358, 2016.

[104] T. Ughetto, "Glucevia Fraxinus excelsior extract effectively controls blood glucose levels in randomized, controlled trial," Integrative Medicine, vol. 13, no. 4, pp. 30-32, 2014.

[105] M. A. Zulet, S. Navas-Carretero, D. Lara Y Sánchez et al., "A Fraxinus excelsior L. seeds/fruits extract benefits glucose homeostasis and adiposity related markers in elderly overweight/ obese subjects: A longitudinal, randomized, crossover, doubleblind, placebo-controlled nutritional intervention study," Phytomedicine, vol. 21, no. 10, pp. 1162-1169, 2014.
[106] Z. Medjahed, D. Atmani-Kilani, M.-L. Fauconnier, G. Richard, and D. Atmani, "Hepatoprotective and antidiabetic activities of Fraxinus angustifolia Vahl extracts in animal models: Characterization by high performance liquid chromatography analysis," Turkish Journal of Medical Sciences, vol. 46, no. 3, pp. 910-920, 2016.

[107] S. F. Abouzid, O. M. Ahmed, R. R. Ahmed, A. Mahmoud, E. Abdella, and M. B. Ashour, "Antihyperglycemic effect of crude extracts of some Egyptian plants and algae," Journal of Medicinal Food, vol. 17, no. 3, pp. 400-406, 2014.

[108] J.-C. Tsai, S. Tsai, and W.-C. Chang, "Effect of ethanol extracts of three Chinese medicinal plants with anti-diarrheal properties on ion transport of the rat intestinal epithelia," Journal of Pharmacological Sciences, vol. 94, no. 1, pp. 60-66, 2004.

[109] C. I. Wright, L. van-Buren, C. I. Kroner, and M. M. G. Koning, "Herbal medicines as diuretics: a review of the scientific evidence," Journal of Ethnopharmacology, vol. 114, no. 1, pp. 1-31, 2007. 


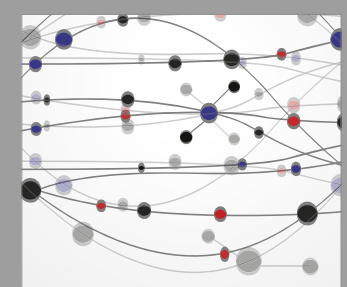

The Scientific World Journal
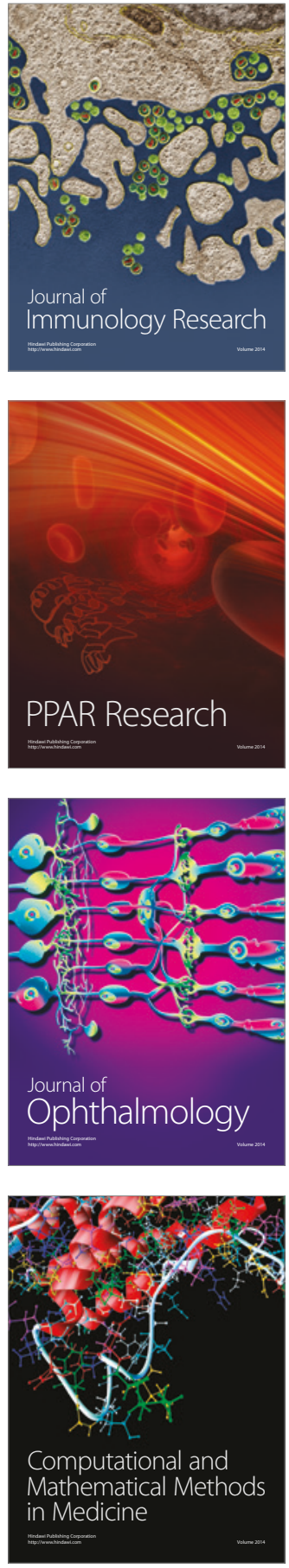

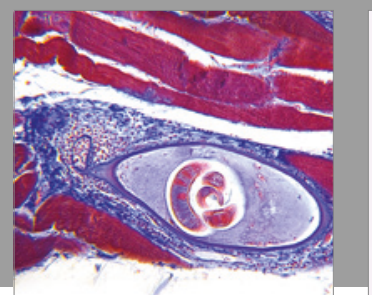

Gastroenterology Research and Practice
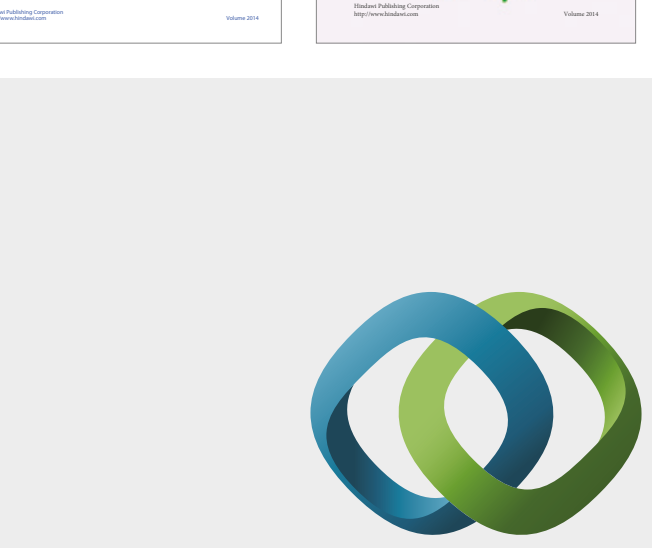

\section{Hindawi}

Submit your manuscripts at

https://www.hindawi.com
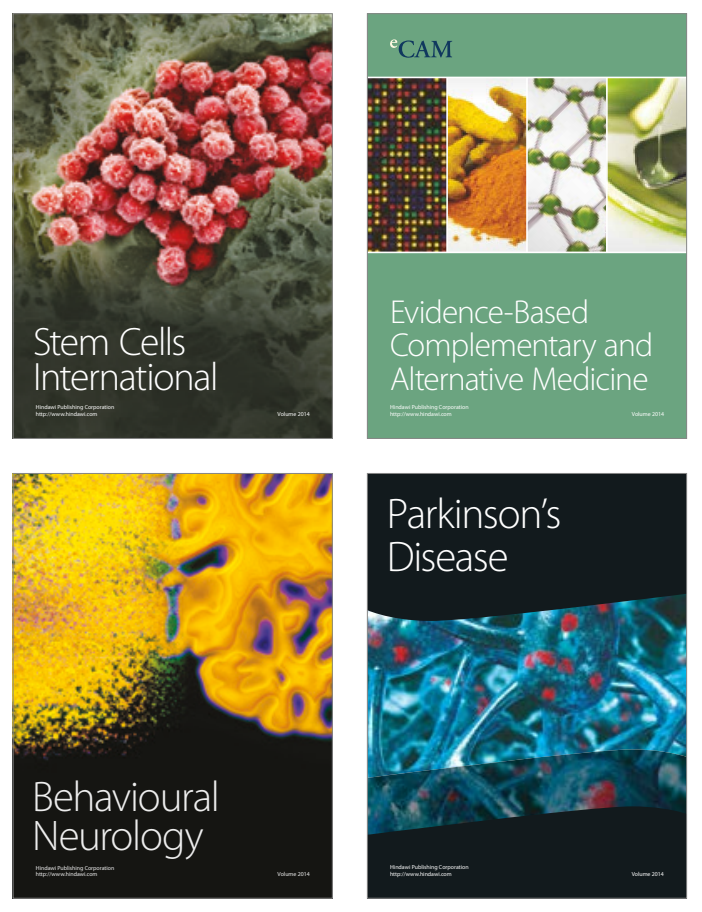
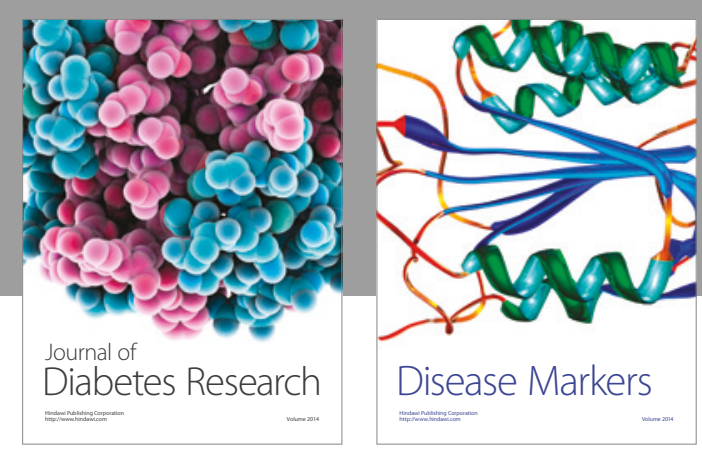

Disease Markers
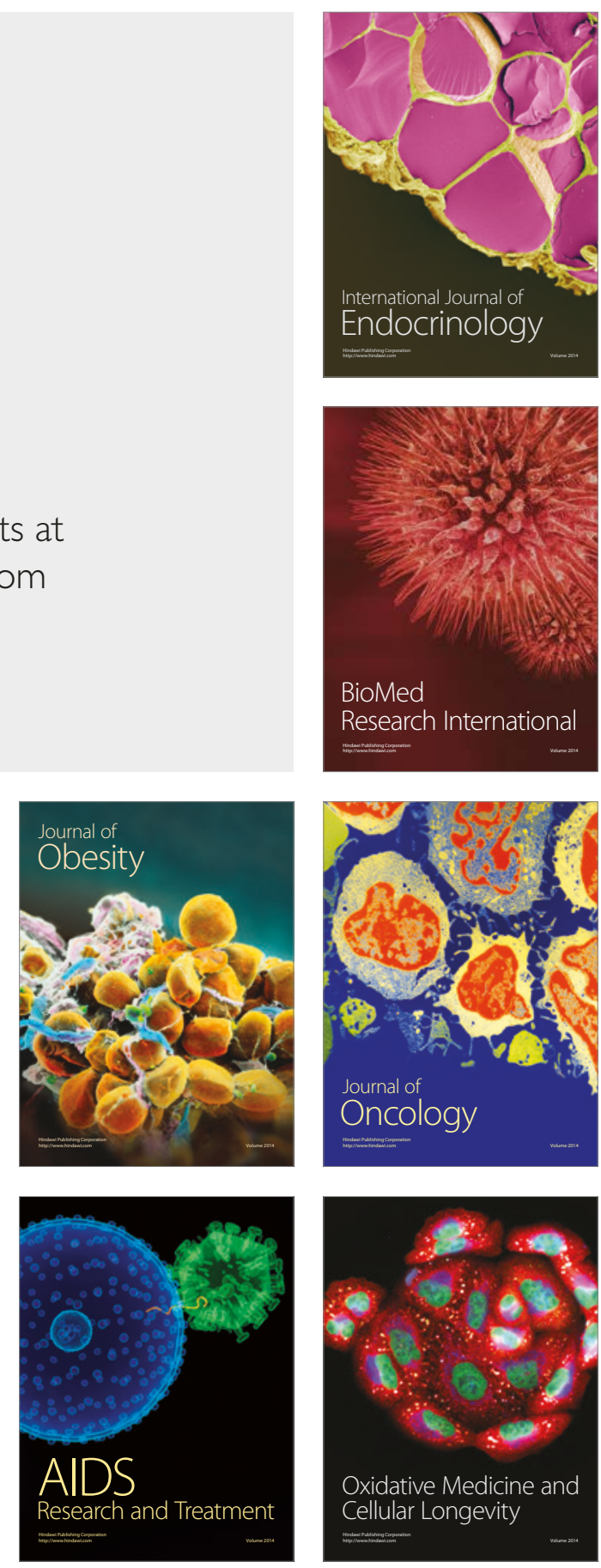